\title{
KESIAPAN SUAMI SEBAGAI PENDAMPING PERSALINAN DI PUSKESMAS PLERET KABUPATEN BANTUL YOGYAKARTA
}

\author{
Rizky Eka Noviana ${ }^{1}$, Dian Puspitasari ${ }^{1}$ \\ ${ }^{1}$ Program Studi Kebidanan (D-3), Stikes Jenderal Achmad Yani Yogyakarta \\ E-mail: dian.ayaniyka@gmail.com
}

\begin{abstract}
Background: On the third trimester of pregnancy, stressors of mother, her husband and family will increasedue to their physical and emotional preparations. Social support is very important for mother prior to labor. Husband's companion in delivery process is perceived very significant. World Health Organization (WHO) suggested that the companion in delivery processis a mother's choice. In Indonesia $68 \%$ delivery are not accompanied by husband. A companion, in particular a significant personduring the process of delivery can shortenthe delivery period, decrease the pain level, lessen the laceration and promote APGAR's score.

Aim: To explore husbands' readiness as companion in delivery process at Puskesmas Pleret, Bantulregency.

Method: This research was a descriptivequantitative research. Samples in the research were chosen with a quota sampling method, consisted of 37 husbands of trimester III mothers and fit in with inclusion and exclusion criteria. Data were collected with a closed questionnaire and were analyzed with univariate analysis.

Result: The majority of respondents were ready as companions in stage I, stage II, stage III and stage IV of the delivery process $(86.5 \%, 70.3 \%, 91.9 \%$, and $83.8 \%$, respectively).

Conclusion: The majority of husbands wereready to accompanythe delivery process at Puskesmas Pleret, Bantul regency(70,3\% respondents).
\end{abstract}

Keywords: readiness, companion of delivery.

\section{PENDAHULUAN}

Data World Health Organization (WHO)

pada tahun 2010, setiap tahun wanita yang bersalin meninggal dunia mencapai lebih dari 536.000 orang. Di negara-negara berkembang hampir 99\% kematian ibu disebabkan persalinan. Rasio kematian ibu di negaranegara berkembang merupakan angka tertinggi dengan 450 kematian ibu per 100.000 kelahiran bayi hidup. ${ }^{(1)}$

Pada tahun 2015 Indonesia memunyai komitmen untuk mencapai target Millenium Development Goals (MDGs), salah satunya menurunkan Angka Kematian Ibu (AKI) menjadi 102 per 100.000 kelahiran hidup dan Angka Kematian Bayi (AKB) dari 68 menjadi 23 per 1000 kelahiran hidup. Berdasarkan data Survei Demografi dan Kesehatan Indonesia (SDKI) tahun 2012 AKI di Indonesia sebesar 359 per 100.000 kelahiran hidup. Semakin tinggi AKI di Indonesia tersebut diperkirakan target MDGs tahun 2015 tidak mudah tercapai. Indonesia merupakan negara dengan AKI tertinggi di Asia Tenggara. Penyebab kematian tertinggi di Indonesia adalah pendarahan sebesar $22,42 \%$, eklampsi sebesar 28, 76\%, infeksi sebesar $3,54 \%$, dan lain-lain sebesar 45, 28\% yang salah satu penyebabnya adalah persalinan lama dan tingginya fertilitas pada usia remaja. ${ }^{(1)}$

Tahun 2008 AKI di Daerah Istimewa Yogyakarta (DIY) mencapai 104 per 100.000 kelahiran hidup. Sedangkan pada tahun 2011, jumlah kasus kematian ibu yang dilaporkan mencapai 56 kasus. Tahun 2012 jumlah kematian ibu menurun menjadi 40 kasus, 
sehingga apabila dihitung menjadi AKI dilaporkan sebesar 87,3 per 100.000 kelahiran hidup. Pada tahun 2010 AKB di Yogyakarta pada laki-laki sebesar 20 bayi per 1000 kelahiran dan perempuan sebesar 14 bayi per 1000 kelahiran hidup. $^{(2)}$

Pada tahun 2012 AKI di Kabupaten Bantul sebesar 52,2 per 100.000 kelahiran hidup. Faktor penyebab AKI di Kabupaten Bantul adalah Pre Eklampsia Berat (PEB) sebesar $29 \%$, pendarahan sebesar $43 \%$, akibat emboli air ketuban sebesar 14\%, dan Cardiomyopati Peripartum sebesar 14\%. AKB di Kabupaten Bantul sebesar 8,6 per 1.000 kelahiran hidup, penyebab kematian bayi terbesar adalah karena asfiksia sebanyak 29 kasus, kematian karena dehidrasi merupakan penyebab terkecil sejumlah 1 kasus.. ${ }^{(3)}$

WHO telah merekomendasikan bahwa pendamping persalinan adalah atas pilihan ibu sendiri, saat ini partisipasi suami dalam kesehatan reproduksi masih rendah. Pendamping, terutama orang terdekat ibu selama proses persalinan dapat membuat persalinan menjadi lebih singkat, nyeri berkurang, robekan jalan lahir jarang, serta nilai APGAR menjadi lebih baik. Masih banyak suami yang belum mampu menunjukkan dukungan penuh terhadap proses persalinan, di Indonesia terdapat $68 \%$ persalinan yang tidak didampingi suami selama proses persalinan. ${ }^{(4)}$

Pada kehamilan trimester III tingkat stresor ibu hamil, suami, dan keluarga akan meningkat karena harus mulai mempersiapkan persalinan baik secara fisik maupun emosional.
Dukungan sosial sangatlah penting diberikan kepada ibu hamil menjelang persalinan dan pada saat persalinan. Pada tahun 1999-2000 pemerintah mengampanyekan program "Suami Siaga" dan pada tahun 2007 pemerintah membentuk Program Perencanaan Persalinan dan Pencegahan Komplikasi (P4K) dengan pemasangan stiker persalinan pada semua rumah ibu hamil. ${ }^{(5)}$

Kesiapan suami sebagai pendamping persalinan dirasakan sangat penting dalam membentuk perilaku seseorang, sehingga beberapa tempat bersalin di Indonesia membuat kebijakan untuk mengikutsertakan suami dalam asuhan kebidanan sebagai pendamping persalinan. Walaupun demikian kebijakan tersebut masih menyimpan keraguan di antara praktisi kesehatan terhadap kesiapan suami sebagai pendamping persalinan. Tenaga kesehatan ikut berperan serta untuk mempersiapkan suami sebagai pendamping persalinan yang baik sesuai dengan tujuan yang diharapkan oleh tenaga kesehatan. ${ }^{(6)}$

Setelah peneliti melakukan studi pendahuluan pada tanggal 20 Januari 2015 di Puskesmas Pleret Kabupaten Bantul peneliti mendapatkan data berupa: Cakupan persalinan yang dilihat dari partograf pada bulan Oktober Desember 2014 sebanyak 11 persalinan (100\%). Dari 11 persalinan tersebut, persalinan yang didampingi oleh keluarga sebanyak 7 orang (64\%) dan didampingi suami sebanyak 4 orang (36\%).Hasil wawancara pada 9 orang suami ibu hamil trimester III (100\%), sebanyak 6 orang suami $(66,6 \%)$ mengatakan 
ketidaksiapannya untuk menjadi pendamping persalinan dikarenakan belum pernah mendampingi persalinan sebelumnya dan pekerjaan yang tidak dapat ditinggalkan, 3 orang suami $(33,3 \%)$ mengatakan siap untuk menjadi pendamping persalinan dikarenakan sebelumnya sudah pernah menjadi pendamping persalinan.

\section{BAHAN DAN CARA PENELITIAN}

Penelitian ini merupakan penelitian deskriptif kuantitatifdan menggunakan alat ukur berupa kuesioner tes tertutup secara tertulis. Penelitian ini dilakukan pada bulan April 2015 dengan sampel suami ibu hamil trimester III yang berada di Puskesmas Pleret Bantul Yogyakarta berjumlah 37 responden dengan teknik quota sampling. Variabel yang digunakan adalah variabel tunggal yaitu kesiapan suami sebagai pendamping persalinan. Analisis data yang digunakan adalah analisis univariat.

\section{HASIL DAN PEMBAHASAN}

Kesiapan suami sebagai pendamping persalinan dijelaskan berdasarkan kategori siap dan tidak siap.

Berdasarkan tabel 1 di bawah ini dapat diketahui bahwa dari 37 suami, mayoritas usia suami berada pada rentang usia 20-35 tahun sebanyak 30 responden(81,1\%), mayoritas kehamilan istri multigravida sebanyak 25 responden (67,6\%), mayoritas suami berpendidikan SMP sebanyak 20 responden $(54,1 \%)$, dan mayoritas suami bekerja sebagai wiraswasta sebanyak 17 responden (45,9\%).

\begin{tabular}{|c|c|c|}
\hline Karakteristik & $\mathbf{F}$ & $(\%)$ \\
\hline \multicolumn{3}{|l|}{ Usia } \\
\hline 15-19 tahun & 3 & 8,1 \\
\hline 20-35 tahun & 30 & 81,1 \\
\hline 36-45 tahun & 4 & 10,8 \\
\hline Jumlah & 37 & 100 \\
\hline \multicolumn{3}{|l|}{ Kehamilan } \\
\hline Kehamilan pertama & 13 & 35,1 \\
\hline Kehamilan ke 2 dan 3 & 24 & 64,9 \\
\hline Jumlah & 37 & 100 \\
\hline \multicolumn{3}{|l|}{ Pendidikan } \\
\hline SD & 3 & 8,1 \\
\hline SMP & 20 & 54,1 \\
\hline SMA & 12 & 32,4 \\
\hline Perguruan Tinggi & 2 & 5,4 \\
\hline Jumlah & 37 & 100 \\
\hline \multicolumn{3}{|l|}{ Pekerjaan } \\
\hline Buruh & 9 & 24,3 \\
\hline Petani & 10 & 27 \\
\hline PNS & 1 & 2,7 \\
\hline Wiraswasta & 17 & 45,9 \\
\hline Jumlah & 37 & 100 \\
\hline
\end{tabular}

Tabel 2 Distribusi Frekuensi Responden Berdasarkan Kesiapan Suami Sebagai Pendamping Persalinan di Puskesmas Pleret Kabupaten Bantul

\begin{tabular}{|c|c|c|}
\hline $\begin{array}{l}\text { Kesiapan Suami sebagai } \\
\text { Pendamping Persalinan }\end{array}$ & $F$ & (\%) \\
\hline Siap & 26 & 70,3 \\
\hline Tidak Siap & 11 & 29,7 \\
\hline Jumlah & 37 & 100 \\
\hline
\end{tabular}

Berdasarkan tabel 2 diketahui bahwa kesiapan suami sebagai pendamping persalinan dalam kategori siap sebanyak 26 responden (70,3\%), dan dalam kategori tidak siap sebanyak 11 responden (29,7\%).

Berdasarkan tabel 3 dapat diketahui bahwa kesiapan suami sebagai pendamping persalinan pada kala I mayoritas dalam kategori siap sebanyak 32 responden (86.5\%), kesiapan suami sebagai pendamping persalinan pada kala II mayoritas dalam kategori siap sebanyak 
26 responden $(70.3 \%)$, kesiapan suami sebagai pendamping persalinan pada kala III mayoritas dalam kategori siap sebanyak 34 responden (91.9\%), kesiapan suami sebagai pendamping persalinan pada kala IV mayoritas dalam kategori siap sebanyak 31 responden (83.8\%).

\section{Tabel 3 Distribusi Frekuensi Responden Kesiapan Suami Sebagai Pendamping Persalinan di Puskesmas Pleret Kabupaten Bantul}

\begin{tabular}{|c|c|c|}
\hline $\begin{array}{c}\text { Kesiapan Suami sebagai } \\
\text { Pendamping Persalinan } \\
\text { pada Kala I }\end{array}$ & $\mathbf{n}$ & (\%) \\
\hline Siap & 32 & 86.5 \\
\hline Tidak Siap & 5 & 13.5 \\
\hline Jumlah & 37 & 100 \\
\hline $\begin{array}{l}\text { Kesiapan Suami Sebagai } \\
\text { Pendamping Persalinan } \\
\text { pada Kala II }\end{array}$ & $\mathbf{n}$ & (\%) \\
\hline Siap & 26 & 70.3 \\
\hline Tidak Siap & 11 & 29.7 \\
\hline Jumlah & 37 & 100 \\
\hline $\begin{array}{c}\text { Kesiapan Suami Sebagai } \\
\text { Pendamping Persalinan } \\
\text { pada Kala III }\end{array}$ & $\mathbf{n}$ & (\%) \\
\hline Siap & 34 & 91.9 \\
\hline Tidak Siap & 3 & 8.1 \\
\hline Jumlah & 37 & 100 \\
\hline $\begin{array}{c}\text { Kesiapan Suami Sebagai } \\
\text { Pendamping Persalinan } \\
\text { pada Kala IV }\end{array}$ & $\mathbf{n}$ & (\%) \\
\hline Siap & 31 & 83.8 \\
\hline Tidak Siap & 6 & 16.2 \\
\hline Jumlah & 37 & 100 \\
\hline
\end{tabular}

\section{Kesiapan Suami Sebagai Pendamping Persalinan}

Dalam penelitian ini kesiapan suami sebagai pendamping persalinan dijelaskan berdasarkan kategori siap dan tidak siap. Dari hasil penelitian pada perilaku atau kesiapan suami sebagai pendamping persalinan pada ibu hamil trimester III menunjukan bahwa mayoritas suami dalam kategori siap sebanyak 26 responden $(70,3 \%)$.
Pendampingan suami adalah suami yang mendampingi istri atau menemani dalam proses persalinan. ${ }^{(7)}$ Pendamping persalinan harus ditentukan jauh sebelum hari persalinan dan pastikan pendamping persalinan cukup usia, cukup matang, dan memiliki kesiapan mental untuk mendukung ibu secara emosional. Dalam hal ini, suami dapat menjadi calon terkuat untuk mendampingi ibu, karena ikatan emosional istri dan suami memang lebih kuat dibandingkan dengan keluargalainnya. Suami bertanggung jawab penuh atas keselamatan istri dan anaknya. Sebagai pendamping persalinan, suami seharusnya membekali dirinya dengan hal-hal berikut yaitu, siap mengajukan pertanyaaan, membawa bekal untuk diri sendiri, mengetahui hal apa yang akan dihadapi, bersikap fleksibel, menemukan pengalihan perhatian, menjadi supporter ibu, mengetahui kapasitas sebagai pendamping, bersiap mengambil alih, siap menunggu, dan selalu di samping ibu. ${ }^{(8)}$

Hasil tabulasi berdasarkan karakteristik usia suami, kategori siap mayoritas ditunjukan pada rentang usia 20-35 tahun sebanyak 22 responden (59,5\%). Suami yang berusia matang (dewasa) akan berusaha semaksimal mungkin memberikan dukungan pendampingan persalinan pada saat istrinya melahirkan. ${ }^{(9)} \mathrm{Hal}$ ini dikarenakan kematangan usia untuk berusaha mengerti tentang psikologis istri pada saat persalinan.

Hasil tabulasi berdasarkan karakteristik riwayat kehamilan, kategori siap mayoritas ditunjukan pada suami ibu hamil ke 2 dan 3 
sebanyak 24 responden (64,9\%). Suami yang memiliki pengalaman sebelumnya di kehamilan pertama akan memiliki kesiapan yang lebih sebagai pendamping persalinan dibandingkan suami yang belum pernah menjadi pendamping persalinan atau suami ibu hamil primigravida. ${ }^{(8)}$

Hasil tabulasi tingkat pendidikan, kategori siap mayoritas ditunjukan pada jenjang pendidikan SMP sebanyak 13 responden $(35,2 \%)$. Berdasarkan data tersebut terlihat bahwa sebagian besar responden telah menempuh pendidikan dasar hingga tingkat pendidikan menengah. Individu yang berpendidikan akan mempunyai pengetahuan tentang pentingnya pendampingan pada saat persalinan, sebaliknya individu yang tidak berpendidikan pengetahuannya akan kurang dan mereka cenderung tidak melakukan pendampingan saat persalinan. ${ }^{(9)}$

Hasil tabulasi pada tingkat pekerjaan responden, kategori siap mayoritas responden bekerja sebagai wiraswasta sebanyak 12 responden (32,4\%). Pekerjaan dan keadaan sosial ekonomi keluarga akan memengaruhi proses pendampingan suami ketika istri melahirkan, suami memunyai tingkat sosial ekonomi yang mapan akan lebih cenderung memperhatikan dan mendampingi istrinya pada saat melahirkan, hal ini berbeda dengan suami yang memunyai status sosial ekonomi yang kurang mampu, suami lebih sibuk untuk mencari biaya persiapan persalinan bagi istrinya. ${ }^{(8)}$

\section{Kesiapan Suami Sebagai Pendamping Persalinan pada Kala I}

Hasil tabulasi tentang kesiapan suami sebagai pendamping persalinan pada kala I menunjukkan hasil perhitungan dengan persentase kategori siap sebanyak 32 responden (86,5\%). Hasil tersebut memberikan gambaran bahwa tingkat kesiapan suami sebagai pendamping persalinan pada kala I sudah baik. Namun dari hasil tabulasi juga didapatkan data yang menunjukkan bahwa 13 responden tidak siap membantu ibu untuk melakukan teknik relaksasi, dan 14 responden tidak siap untuk memantau istri secara langsung dalam proses persalinan dengan memperhatikan kontraksi.

Suami sebagai pendamping persalinan ikut memainkan peranan penting dalam mengikuti seluruh proses persalinan. Berbagai cara yang dilakukan suami saat mendampingi persalinan antara lain: mengukur lamanya waktu kontraksi, bernapas seirama, membantu menopang istrinya, memberi pijatan lembut pada punggung atau perut ibu, menyuguhkan minum, menyampaikan pesan istri kepada petugas kesehatan, memberikan perhatian, dan mendorong semangat. ${ }^{(9)}$

\section{Kesiapan Suami Sebagai Pendamping Persalinan pada Kala II}

Hasil tabulasi data kesiapan suami sebagai pendamping persalinan pada kala II menunjukkan hasil perhitungan dengan persentase kategori siap sebanyak 26 responden $(70,3 \%)$, hal tersebut mengalami penurunan kesiapan dibandingkan dengan kesiapan suami pada kala I. Meski mengalami 
penurunan persentase, hasil tersebut memberikan gambaran bahwa tingkat kesiapan suami sebagai pendamping persalinan pada kala II sudah baik. Namun dari hasil tabulasi tiap poin dalam kuesioner didapatkan data yang menunjukkan bahwa 13 responden tidak siap untuk mendampingi istri pada saat proses persalinan keluarnya bayi, 19 responden lebih suka mendampingi istri hingga bayi lahir saja dan setelah itu keluar dari ruang bersalin, 14 responden memilih menunggu di luar ruang bersalin saat mendampingi istri, dan 14 responden merasa bukan orang terbaik untuk menjadi pendamping istri selama proses persalinan keluarnya bayi. Hal ini dikarenakan sebagian responden tidak siap secara usia, mental, dan kurang paham dengan peran yang seharusnya dilakukan pada kala II.

\section{Kesiapan Suami Sebagai Pendamping Persalinan pada Kala III}

Kesiapan suami sebagai pendamping persalinan pada kala III mengalami peningkatan dibandingkan dengan kesiapan suami pada kala II. Hal ini ditunjukkan dari hasil perhitungan tabulasi data dengan persentase kategori siap sebanyak 34 responden (91,9\%). Jika dilihat dari peritem kuesioner didapatkan hasil tabulasi bahwa 11 responden tidak siap untuk mendampingi istri saat proses persalinan keluarnya ari-ari, dan 10 responden tidak siap beradaptasi dengan baik selama proses persalinan keluarnya ari-ari. Hal ini dikarenakan sebagian responden kurang paham dengan peran yang seharusnya dilakukan pada kala III.

\section{Kesiapan Suami Sebagai Pendamping Persalinan pada Kala IV}

Berdasarkan tabel 3, tabulasi data kesiapan suami sebagai pendamping persalinan pada kala IV menunjukkan hasil perhitungan dengan persentase kategori siap sebanyak 31 responden (83,8\%). Hasil tersebut jika dilihat dari item pernyataan pada kuesioner memberikan gambaran bahwa tingkat kesiapan suami sebagai pendamping persalinan pada kala IV sudah baik. Namun dari hasil tabulasi juga didapatkan data yang menunjukan bahwa 14 responden tidak siap untuk mendampingi istri pada saat proses dua jam pengawasan setelah keluarnya ari-ari. Hal ini dikarenakan sebagian responden kurang paham dengan peran yang seharusnya dilakukan pada kala IV.

\section{KESIMPULAN}

Berdasarkan uraian hasil penelitian dan pembahasan di atas maka kesimpulan yang dapat peneliti ambil adalah kesiapan suami sebagai pendamping persalinan di Puskesmas Pleret Kabupaten Bantul mayoritas dalam kategori siap sebanyak 26 responden (70,3\%). Kesiapan suami sebagai pendamping persalinan di Puskesmas Pleret Kabupaten Bantul mayoritas pada rentang usia 20-35 tahun sebanyak 30 responden $(81,1 \%)$, kehamilan ke 2 dan 3 sebanyak 25 responden $(67,6 \%)$, suami berpendidikan SMP sebanyak 20 responden $(54,1 \%)$, dan suami bekerja sebagai wiraswasta sebanyak 17 responden (45,9\%)

Kesiapan suami sebagai pendamping persalinan pada kala I mayoritas dalam kategori 
siap yaitu dengan jumlah sebanyak 32 responden (86,5\%). Kesiapan suami sebagai pendamping persalinan pada kala II mayoritas dalam kategori siap yaitu dengan jumlah sebanyak 26 responden (70,3\%). Kesiapan suami sebagai pendamping persalinan pada kala III mayoritas dalam kategori siap yaitu dengan jumlah sebanyak 34 responden $(91,9 \%)$. Kesiapan suami sebagai pendamping persalinan pada kala IV mayoritas dalam kategori siap yaitu dengan jumlah sebanyak 31 responden (83,8\%).

Berdasarkan penelitian yang telah dilakukan, maka peneliti memberikan saransaran yaitu diharapkan dapat digunakan sebagai acuan dan wawasan mengenai pentingnya kesiapan suami sebagai pendamping persalinan dan sebagai studi pendahuluan untuk penelitian lebih lanjut yaitu diharapkan bagi para suami hendaknya berkelanjutan untuk mencari informasi tentang kesiapan suami sebagai pendamping persalinan baik dengan cara mengikuti penyuluhan yang dilakukan tenaga kesehatan, dari berbagai media baik media cetak maupun media elektronik.

Diharapkan dapat menjadi dasar bagi tenaga kesehatan Puskesmas Pleret Kabupaten Bantul untuk selalu memantau dan monitoring terhadap para suami dengan memberikan motivasi untuk ikut serta dalam program Kesehatan Ibu dan Anak (KIA) khususnya kesiapan suami sebagai pendamping persalinan, serta melakukan penyuluhan dengan cara memutarkan video persalinan normal agar para suami dapat memahami peran pada saat proses persalinan.

Diharapkan dapat menambah referensi kesehatan tentang kesiapan suami sebagai pendamping persalinan di perpustakaan dan sebagai bahan bacaan. Diharapkan peneliti yang akan datang dapat memperluas ruang lingkup penelitian ini agar lebih sempurna dan bermanfaat, serta dapat mengembangkan variabel seperti mengobservasi pada saat proses persalinannya secara langsung tidak hanya pada TM III saja.

\section{KEPUSTAKAAN}

1. SDKI. (2012). Angka Kematian Ibu Melonjak, Indonesia Mundur 15 tahun. http://theprakarsa.org/new/ck uploads /files/Prakarsa\%20Policy Oktober Rev31.pdf. (Di akses pada tanggal 14 Januari 2015 pukul 06.21 WIB

2. Dinkes Bantul. Profil Kesehatan Kabupaten Bantul. Yogyakarta: Dinkes Bantul. 2013

3. Dinkes DIY. Profil Kesehatan DIY. Yogyakarta: Dinkes DIY. 2013

4. Darsana, Pendamping Persalinan. Jakarta: EGC. 2009

5. Depkes RI. Asuhan Persalinan Normal. Jakarta: Depkes RI. 2008

6. Widyaningsih, R. Sikap suami sebagai pendamping persallinan. Skripsi: Jakarta. 2012 (Di akses pada tanggal 7 Desember 2014 pukul 09.10 WIB).

7. Bobak., Lowdermilk. Buku Ajar Keperawatan Maternitas. Jakarta: Swara. 2005 
8. Notoatmodjo, S. Metodologi Penelitian Kesehatan. Jakarta: PT Rineka Cipta. 2010

9. Yanti. Buku Ajar Asuhan Kebidanan Persalinan. Yogyakarta: Pustaka Rihama. 2009 